\title{
On the Changes in the Minute Volume and the Stroke Volume of the Heart following the Respiration of Compressed Air.
}

\author{
By \\ KATSUTAKA KATO. \\ (b口) 藤 克 管) \\ (From the Laboratory of Prof. T. Kato's Medical Clinic, \\ Tohoku Imperial Unirersity, Sondai.)
}

Various changes in organisms provoked by the respiration of compressed air have already been investigated by some experimentators.

In the course of an experiment with the respiration of compressed air, Sommerbrod $t^{1}$ observed a decrease of blood pressure, and attributed this phenomenon to the lessening of the rolume of blood in the arterial system, on account of the disturbance in circulation from the renous system to the arterial side which was aroused by the compression of capillaries in the lungs due to the elerated gas pressure. T'i $\mathrm{eg}^{2} \mathrm{l}^{2}$ ) has found that during exposure at un excessive pressure the blond pressure in the endothoracic veins is elevated, a stasis takes place in the peripheral veins and the blood-flow into the endothoracic reins is disturbed, in consequence of the excessire pressure in the thoracic cavity. On observing also that the blood pressure is augmented in the pulmonal arteries, he attributed this occurrence to the extensive re-istance in the blood-flow, which is induced by the compression of the lung cajillaries due to the high pressure in the alreoli.

Lecently, $\mathrm{Hugget} \mathrm{t}^{3}$ investigated the heart output during respiratory obstruction. He used urethanised cats for the experiments. The obstruction used was threefold:namely, simple incpiratory, simple expiratory and combined inspiratory and expiratory obstruction. Into the trichea a cannula of $\mathrm{Y}$-shape was inserted, one limb of which was connected by wide rubber tubing to a wash-bottle containing water so that the air which was to be breathed in passed through the bottle. The pressure was regulated by the depth of the inflow tube below the water. A similar but reversed bottle gave the expiratory resistance. In the ca e of an inspiratory obstruction of $\bar{j} \mathrm{~cm}$. of water, the animal would have to lower the pressure inide the buttle to $5 \mathrm{~cm}$. below the atmospheric pressure by expanding the chest, in order that air might pass down the entry tube of the bottle. Similarly, in the resersed (expiratory) bottle the animal would have to create positive pressure in order to drice the air out, thu giving rise to a forced expiration. Under such conditions the mi-

1) Sommerbrodt, cited by Full and Friedrich. Klin. Wochenschr., 192:, 69.

2) Tiegel, Brun's Beitrige z. klin. Chirurg., 1911, 76, 160.

3) Hugget, Journ. Physiol., 1924, 59, 378. 
nute rolume and the stroke volume were measured by Fick's formula. Inspiratory obstruction increased the minute volume by 37.5 p.c. and the stroke rolume by 43 p.c. Expiratory obstruction decreased both minute volume and the stroke volume by 33 p.c. Combined inspiratory and expiratory obstruction caused a decrease in the minute rolume by 31 p.e. and in the stroke volume by 23.5 p.c.

Motek $\mathrm{i}^{\mathrm{t}}$ of our Laboratory using rabbits investigated the changes in respiration, pulse rate, blood gases, blood elements and total blood volume, due to the respiration of air under an excess of pressure, which amounted to from 10 to $15 \mathrm{~cm}$. of water. He summarized his experimental results as follows: The oxygen unsaturation of arterial blood decreased markedly by the inhalation of the compressed air for one hour, and increased tbereafter without reaching the initial ralue. After the cessation of the inhalation it showed in general a tendency to decrease a little again. The oxygen capacity of the blood was already at the end of the first hour of the inhalation markedly diminished, and as a rule further decrease was observed still after the decompression, with a few exceptions when there was an increase. The content of carbon dioxide in the blood indicated also a decrease during the respiration of compressed air in the majority of cases, and decreased after the cessation of it more and more. The haemoglobin and serum protein showed a remarkable decrease during the exposure at excess pressure, and a tendency to recover after the decompression; but serum sodium chloride showed a slight decrease one hour after the exposure, and an increase two hours after it, and this tendency to increase continued even after the cessation of the exposure. The total blood volume increased remarkably during the inhalation of compressed air, and recovered after returning to normal respiration. During the respiration of compressed air, the blood pressure and respiration rate fell and the pulse rate increased, but recovered when respiration was resumed under nornal conditions.

In the present investigation I have undertaken to observe the effects of the respiration of compressed air on the minute volume and the stroke volume of the heart.

Method of Experiment:-The animals used for the experiments were rabbits. Without anaesthetics the animal was fixed in the dorsal position on an animal holder, which was suitably warmed. The cannulae were inserted into the trachea and the femoral artery, and the skin was resected from the cardiac area. The experiment was not begun until the respiration became quiet, after the animal had been lying still for one hour. The excess pressure was made by putting a weight of 3 kilogrammes on the bell of Sa $\mathrm{n}$ born-Benedict's respiration apparatus with which a water manometer was connected, indicating the pressure to be higher by about $14 \mathrm{~cm}$. of water than the atmospheric pressure. The determination of the minute volume was carried out by Fick's's principle. The oxygen consumption was measured with Sanborn-Benedict's respiration apparatus. The arterial blood was drawn from the femoral artery. The mixed venous

4) Moteki, Nihon-Nuika-Grakkai-Zashi, 1925, 13, 121.

5) Fick, Verhand. d. physik. med. Gesellsch. in Wirzburg, 1872, 2, 16, eited by Lundsga ard, Deutsh. Areh. f. kl. Med., 1916, 118, 36 . 
blood was taken from the right ventricle by cardiac puncture through the thorax wall. The 2 c.c. syringe used for the purpose was graduated exactly, containing 3.5 p.c. sodium citrate in the dead space of the barrel and the needle, which was $5.5 \mathrm{~cm}$. long and of $0.5 \mathrm{~mm}$. calibre. The blood obtained was immediately transferred to a Bareroft's bottle and the arteriovenous difference of oxygen contents was measured. These measurements were made five times, $i$. e. before the respiration of compressed air, one and two hours after the exposure at excess pressure and one and tro hours after the cessation of the pressure. All care was taken to keep the animals quiet during the experiments, because the disquiet of the animals changes the gaseous metabolism and the circulation.

\section{Results of the Exuenments.}

Eleven experiments were made, the results of which are shown in Table I.

\section{TABLE I.}

Changes in the ITeart Output by Respiration of Conpressed Air.

\begin{tabular}{|c|c|c|c|c|c|c|c|c|c|c|}
\hline$\dot{z}$ & 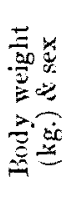 & Time of observation & 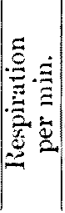 & 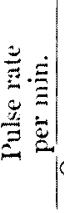 & 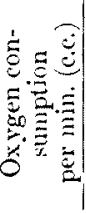 & 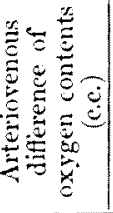 & $\begin{array}{l}\text { Min } \\
\text { rolu }\end{array}$ & 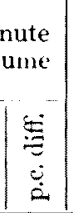 & $\begin{array}{c}\text { Stro } \\
\text { volu } \\
\qquad \\
ن\end{array}$ & 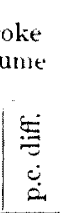 \\
\hline 1 & $\begin{array}{c}1.87 \\
f\end{array}$ & $\begin{array}{l}\text { Before compression } \\
1 \text { hr. after compression } \\
2 \text { hrs. after comprescion } \\
1 \text { hr. after decompression } \\
2 \text { hrs. after decompression }\end{array}$ & $\begin{array}{l}48 \\
48 \\
46 \\
44 \\
44\end{array}$ & $\begin{array}{l}270 \\
252 \\
240 \\
240 \\
270\end{array}$ & $\begin{array}{l}29.89 \\
18.94 \\
18.94 \\
22.41 \\
23.85\end{array}$ & $\begin{array}{l}0.09900 \\
0.10427 \\
0.11129 \\
0.10356 \\
0.08566\end{array}$ & $\begin{array}{l}302 \\
182 \\
170 \\
216 \\
273\end{array}$ & $\mid \begin{array}{r}-40 \\
-44 \\
-28 \\
-10\end{array}$ & $\begin{array}{l}1.12 \\
0.72 \\
0.70 \\
0.90 \\
1.01\end{array}$ & $\begin{array}{l}-36 \\
-38 \\
-20 \\
-10\end{array}$ \\
\hline 2 & $\begin{array}{c}2.12 \\
9\end{array}$ & $\begin{array}{l}\text { Before compression } \\
1 \mathrm{hr} \text {. after compression } \\
2 \mathrm{hrs} \text {. after compression } \\
1 \mathrm{hr} \text { : ifter decompression } \\
2 \mathrm{hrs} \text {. after decompression }\end{array}$ & $\begin{array}{l}62 \\
56 \\
56 \\
64 \\
66\end{array}$ & $\begin{array}{l}222 \\
216 \\
218 \\
210 \\
216\end{array}$ & $\begin{array}{l}27.51 \\
30.27 \\
28.35 \\
20.48 \\
20.50\end{array}$ & $\begin{array}{l}0.06045 \\
0.10906 \\
0.08597 \\
0.04678 \\
0.04475\end{array}$ & $\begin{array}{l}455 \\
278 \\
330 \\
438 \\
458\end{array}$ & $\left|\begin{array}{r}-31 \\
-27 \\
-27 \\
-4 \\
-1\end{array}\right|$ & $\begin{array}{l}2.05 \\
1.29 \\
1.51 \\
2.09 \\
2.12\end{array}$ & $\begin{array}{r}-42 \\
-26 \\
\div 2 \\
\div \quad 8\end{array}$ \\
\hline 3 & $\begin{array}{c}1.77 \\
9\end{array}$ & $\begin{array}{l}\text { Before compression } \\
1 \mathrm{hr} \text {. after compression } \\
2 \mathrm{hrs} \text {. after compression } \\
1 \mathrm{hr} \text {. after decompression } \\
2 \mathrm{hrs} \text {. after decompression }\end{array}$ & $\begin{array}{r}88 \\
95 \\
83 \\
116\end{array}$ & $\begin{array}{l}258 \\
270 \\
198 \\
270\end{array}$ & $\begin{array}{l}21.72 \\
22.10 \\
17.70 \\
17.67\end{array}$ & $\begin{array}{l}0.07858 \\
0.11408 \\
0.06992 \\
0.07068\end{array}$ & $\begin{array}{l}276 \\
194 \\
253 \\
250\end{array} \mid$ & $\left|\begin{array}{r}-30 \\
-8 \\
-10\end{array}\right|$ & $\begin{array}{l}1.07 \\
0.72 \\
1.28 \\
0.93\end{array}$ & $\begin{array}{r}-30 \\
-30 \\
-30 \\
-13\end{array}$ \\
\hline 4 & $\begin{array}{c}2.40 \\
9\end{array}$ & $\begin{array}{l}\text { Pefore compression } \\
1 \mathrm{hr} \text {. after compression } \\
2 \mathrm{hrs} \text {. after compression } \\
1 \mathrm{hr} \text { after decompression } \\
2 \mathrm{hrs} \text {. after decompression }\end{array}$ & $\begin{array}{l}70 \\
88 \\
74 \\
72 \\
80\end{array}$ & $\begin{array}{l}288 \\
288 \\
258 \\
282 \\
270\end{array}$ & $\begin{array}{l}25.68 \\
19.49 \\
19.54 \\
27.84 \\
22.85\end{array}$ & $\begin{array}{l}0.08789 \\
0.09744 \\
0.10715 \\
0.11337 \\
0.08423\end{array}$ & $\mid \begin{array}{l}292 \\
200 \\
182 \\
246 \\
271\end{array}$ & $\begin{array}{r}-32 \\
-32 \\
-36 \\
-16 \\
-7\end{array}$ & $\begin{array}{l}1.01 \\
0.69 \\
0.71 \\
0.87 \\
1.00\end{array}$ & $\begin{array}{r}-3 \\
-32 \\
-30 \\
-14 \\
-1\end{array}$ \\
\hline
\end{tabular}




\begin{tabular}{|c|c|c|c|c|c|c|c|c|c|c|}
\hline \multirow{2}{*}{$\dot{\bar{z}}$} & \multirow{2}{*}{ 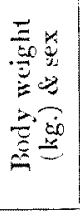 } & \multirow{2}{*}{ Time of ubservation } & \multirow{2}{*}{ 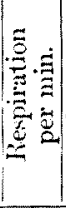 } & \multirow{2}{*}{ 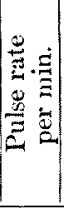 } & \multirow{2}{*}{ 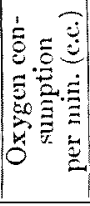 } & \multirow{2}{*}{ 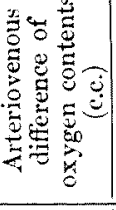 } & \multicolumn{2}{|c|}{$\begin{array}{l}\text { Minute } \\
\text { volume }\end{array}$} & \multicolumn{2}{|c|}{$\begin{array}{l}\text { Stroke } \\
\text { volume }\end{array}$} \\
\hline & & & & & & & نُ & 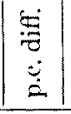 & نُ & 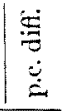 \\
\hline 5 & 2.40 & $\begin{array}{l}\text { liefore compresion } \\
1 \text { hr. after compression } \\
2 \text { hrs. after compression } \\
1 \text { hr. after decompreswion } \\
2 \text { hrs. after decompression }\end{array}$ & $\begin{array}{l}48 \\
58 \\
56 \\
58 \\
54\end{array}$ & $\begin{array}{l}246 \\
258 \\
270 \\
246 \\
258\end{array}$ & $\begin{array}{l}20.55 \\
20.83 \\
21.78 \\
21.51 \\
24.36\end{array}$ & $\begin{array}{l}0.08254 \\
0.08958 \\
0.08223 \\
0.06929 \\
0.07478\end{array}$ & $\begin{array}{l}249 \\
233 \\
265 \\
310 \\
326\end{array}$ & $\begin{array}{r} \\
-6 \\
+6 \\
+25 \\
+31\end{array}$ & $\begin{array}{l}1.01 \\
0.90 \\
0.98 \\
1.26 \\
1.26\end{array}$ & $\begin{array}{r}-11 \\
-3 \\
+25 \\
+25\end{array}$ \\
\hline i & $\begin{array}{c}2.15 \\
7\end{array}$ & $\begin{array}{l}\text { Jefore compression } \\
1 \text { hr. after compression } \\
2 \text { hr. after compression } \\
1 \text { hr. after decomprestion } \\
2 \text { hr. after decompression }\end{array}$ & $\begin{array}{r}120 \\
62 \\
76 \\
74\end{array}$ & $\begin{array}{l}228 \\
216 \\
228 \\
228\end{array}$ & $\begin{array}{l}28.47 \\
21.25 \\
25.65 \\
21.71\end{array}$ & $\begin{array}{l}0.11629 \\
0.13569 \\
0.09468 \\
0.09550\end{array}$ & $\begin{array}{l}246 \\
157 \\
271 \\
227\end{array} \mid$ & $\begin{array}{r}-36 \\
+10 \\
-8\end{array}$ & $\begin{array}{l}1.08 \\
0.73 \\
1.19 \\
1.00\end{array}$ & $\begin{array}{l}-32 \\
+10 \\
-7\end{array}$ \\
\hline 7 & $\begin{array}{c}2.80 \\
\div\end{array}$ & $\begin{array}{l}\text { Pefore comprescion } \\
1 \mathrm{hr} \text { atter compression } \\
2 \mathrm{hr} \text {. after compresion } \\
1 \mathrm{hr} \text {. after decompression } \\
2 \mathrm{hr} \text {. after decompression }\end{array}$ & $\begin{array}{r}183 \\
95 \\
90 \\
111 \\
88\end{array}$ & $\begin{array}{l}246 \\
216 \\
216 \\
240 \\
240\end{array}$ & $\begin{array}{l}23.69 \\
18.57 \\
18.55 \\
17.36 \\
17.44\end{array}$ & $\left|\begin{array}{l}0.12132 \\
0.09646 \\
0.09886 \\
0.09928 \\
0.07789\end{array}\right|$ & $\begin{array}{l}195 \\
193 \\
189 \\
175 \\
224\end{array}$ & $\begin{array}{r} \\
-1 \\
-3 \\
-10 \\
+15\end{array}$ & $\begin{array}{l}0.79 \\
0.89 \\
0.87 \\
0.73 \\
0.91\end{array}$ & $\begin{array}{r} \\
+13 \\
+10 \\
-8 \\
+15\end{array}$ \\
\hline 8 & $\begin{array}{c}1.95 \\
\frac{9}{9}\end{array}$ & $\begin{array}{l}\text { Before compression } \\
1 \mathrm{hr} \text {. after compression } \\
2 \mathrm{hrs} \text {. after compression } \\
1 \mathrm{hr} \text {. after decompression } \\
2 \mathrm{hrs} \text {. after decompresion }\end{array}$ & $\begin{array}{l}47 \\
58 \\
63 \\
49 \\
61\end{array}$ & $\begin{array}{l}267 \\
246 \\
243 \\
276 \\
264\end{array}$ & $\begin{array}{l}21.35 \\
12.37 \\
12.06 \\
10.96 \\
13.26\end{array}$ & $\begin{array}{l}0.06073 \\
0.12924 \\
0.12560 \\
0.08085 \\
0.10136\end{array}$ & $\begin{array}{r}952 \\
96 \\
96 \\
136 \\
132\end{array}$ & $\left|\begin{array}{r}-79 \\
-73 \\
-61 \\
-63\end{array}\right|$ & $\begin{array}{l}1.32 \\
0.39 \\
0.40 \\
0.49 \\
0.50\end{array}$ & $\begin{array}{l}-70 \\
0-70 \\
9-63 \\
0 \\
0.62\end{array}$ \\
\hline 9 & $\begin{array}{c}2.10 \\
?\end{array}$ & $\begin{array}{l}\text { Before compression } \\
1 \mathrm{hr} \text {. after compression } \\
2 \mathrm{hrs} \text {. after compression } \\
1 \mathrm{hr} \text {. after decompression } \\
2 \mathrm{hrs} \text {. after decomprescion }\end{array}$ & $\begin{array}{l}40 \\
56 \\
52 \\
40 \\
40\end{array}$ & $\begin{array}{l}180 \\
204 \\
210 \\
156 \\
180\end{array}$ & $\begin{array}{l}.4 .21 \\
19.50 \\
16.97 \\
17.56 \\
16.7 .2\end{array}$ & $\begin{array}{l}0.06: 391 \\
0.08761 \\
0.08592 \\
0.07893 \\
0.05461\end{array}$ & $\begin{array}{l}379 \\
227 \\
191 \\
228 \\
306\end{array}$ & $\begin{array}{r} \\
-40 \\
-50 \\
-41 \\
-20\end{array}$ & $\begin{array}{l}2.11 \\
1.11 \\
0.9 ! \\
1.42 \\
1.70\end{array}$ & $\begin{array}{l}1 \\
-47 \\
-57 \\
-33 \\
-39 \\
-19\end{array}$ \\
\hline 10 & $\begin{array}{c}2.26 \\
?\end{array}$ & $\begin{array}{l}\text { Before compression } \\
1 \text { hr. after compression } \\
2 \text { hrs. after compression } \\
1 \text { hr. after decompression } \\
2 \text { hrs. after decompression }\end{array}$ & $\begin{array}{r}72 \\
60 \\
68 \\
108 \\
151\end{array}$ & $\begin{array}{l}288 \\
237 \\
228 \\
228 \\
220 \\
220\end{array}$ & $\begin{array}{l}26.38 \\
24.80 \\
19.08 \\
21.55 \\
23.39\end{array}$ & $\begin{array}{l}0.06471 \\
0.07693 \\
0.05813 \\
0.07497 \\
0.06827\end{array}$ & $\mid \begin{array}{l}408 \\
322 \\
328 \\
287 \\
343\end{array}$ & $\left|\begin{array}{l}-21 \\
-20 \\
-30 \\
-16\end{array}\right|$ & $\begin{array}{l}1.83 \\
1.36 \\
1.44 \\
1.28 \\
1.55\end{array}$ & \begin{tabular}{|l|l}
8 & -26 \\
4 & -26 \\
5 & -30 \\
5 & -15
\end{tabular} \\
\hline 11 & $\begin{array}{c}206 \\
7\end{array}$ & $\begin{array}{l}\text { Before compression } \\
1 \text { hr. after compression } \\
2 \text { hrs. after compression } \\
1 \text { hr. after decompression } \\
2 \text { hrs. after decompression }\end{array}$ & $\begin{array}{l}45 \\
49 \\
48 \\
50\end{array}$ & $\begin{array}{l}2: 34 \\
264 \\
267 \\
246\end{array}$ & $\begin{array}{l}18.60 \\
18.27 \\
17.65 \\
17.81\end{array}$ & $\begin{array}{l}0.08476 \\
0.10526 \\
0.10762 \\
0.10464\end{array}$ & $\begin{array}{l}220 \\
174 \\
164 \\
170\end{array}$ & $\mid \begin{array}{l}-21 \\
-25 \\
-23\end{array}$ & $\begin{array}{l}0.94 \\
0.66 \\
0.61 \\
0.69\end{array}$ & $\begin{array}{l}4 \\
6-30 \\
1-35 \\
9-27\end{array}$ \\
\hline 窵 & & $\begin{array}{l}\text { Before compresion } \\
1 \mathrm{hr} \text {. after compresion } \\
2 \mathrm{hrs} \text {. after compression } \\
1 \mathrm{hr} \text {. after decompression } \\
2 \mathrm{hr} \text {. after decompression }\end{array}$ & $\begin{array}{l}75 \\
65 \\
61 \\
69 \\
77\end{array}$ & $\mid \begin{array}{l}242 \\
242 \\
235 \\
243 \\
242\end{array}$ & $\begin{array}{l}23.92 \\
20.61 \\
19.21 \\
20.08 \\
20.14\end{array}$ & $\mid \begin{array}{l}0.08365 \\
0.10415 \\
0.09614 \\
0.08511 \\
0.08579\end{array}$ & $\begin{array}{l}307 \\
205 \\
213 \\
248 \\
281\end{array}$ & $\left|\begin{array}{r}-33 \\
-31 \\
-20 \\
-8\end{array}\right|$ & $\begin{array}{l}1.30 \\
0.30 \\
0.90 \\
1.11 \\
1.20\end{array}$ & \begin{tabular}{l|l}
0 & \\
6 & -34 \\
0 & -31 \\
1 & -315 \\
0 & -8
\end{tabular} \\
\hline
\end{tabular}


Fig. 1.

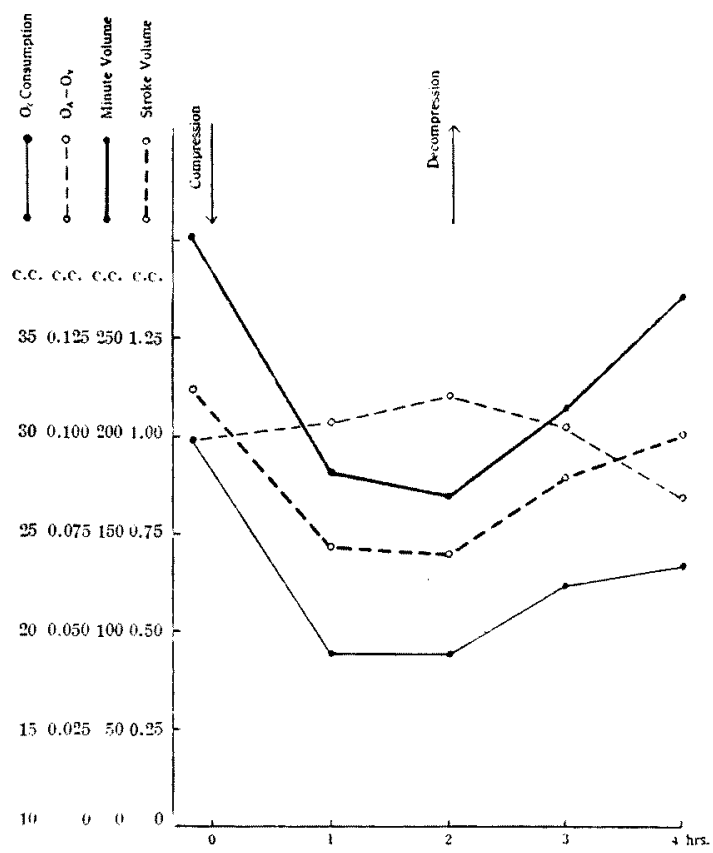

Experiment No. 1, Table I.

Before the breathing of compressed air the minute volume amounted to from 455 to 195 c.c. with an average of 307 c.c. Being exposed for one hour at the excess pressure, it decreased markedly, amounting to from 322 to 96 c.c., with an a verage of 205 c.c., in two hours to from 330 to 96 c.c. on an average to 213 c.e. After the cessation of the exposure at the excess pressure it increased gradually :-namely one hour after the cessation it was raised to from 438 to 136 c.c. with an average of 248 c.c., two hours thereafter returning to from 458 to 132 c.c. with an average of 281 c.c. In brief, it can be clearly seen that the minute volume which has decreased during the respiration of compressed air begins to increase after the cessation of this respiration, but does not yet reach the former value.

The stroke volume also showed a tendency resembling that of the minute volume. Before the compressed air was inhaled, the stroke rolume amounted to from 2.11 to $0.79 \mathrm{ccc}$. with an average of $1.30 \mathrm{c.c} \cdot$, but during the respiration of compressed air it decreased markedly, i. e. one hour after the commencement of inhalation of the compressed air it was reduced to 
from 1.36 to 0.39 c.e. with an average of 0.86 c.c., in two hours to from 1.51 to 0.40 c.c. with an average of 0.90 c.c. After removing the excess pressure, the stroke volume increased :-namely, one hour after the normal respiration it amounted to from 2.09 to 0.49 e.c. with an average of 1.11 c.c.; two hours thereafter, returning to from 2.12 to 0.50 c.c. on an average to 1.20 c.c. These facts agree with the results which $\mathrm{Hugget} \mathrm{t}^{3)}$ obtained in his investigation, using the expiratory obstruction.

The oxygen consumption per minute amounted to from 29.89 to 18.66 c.c. with an a verage of 23.92 c.c. before the inhalation of the compressed air. During the inhalation of compressed air it was lessened in one hour to from 30.27 to 12.37 c.c. with an average of 20.61 c.c. and in two hours to from 28.35 to 12.06 c.c. on an average to 19.21 c.c. One hour after removing the compressed air, it was raised a little showing values fluctuating from 27.84 to 10.96 c.c. with an average of 20.08 c.c., but even after two hours it could not completely recover, amounting to from 24.36 to 13.36 c.c. with an average of 20.14 c.c.

The arteriovenous difference of oxygen contents per c.c. of blood, i. e. oxygen utilisation, which amounted to from 0.12132 to 0.06045 c.c. with an average of 0.08365 c.c. before the compressed air was inhaled, increased markedly during the inhalation of it, being augmented in one hour to from 0.13569 to 0.07695 c.c. with an average of 0.10415 c.c., in two hours to from 0.12560 to 0.05813 c.c. with an a verage of 0.09614 c.c. Respiration at normal pressure brought it to decrease more or less:- namely in one hour it was lowered to from 0.11337 to 0.04678 c.c. with an average of 0.08511 c.c., in two hours keeping the value from 0.10136 to 0.04475 c.c. with an average of 0.08579 c.e.

To ascertain the results above mentioned, in an experiment compression was given once more two hours after the decompression, as is shown

TABLE II.

\begin{tabular}{|c|c|c|c|c|c|c|c|c|c|}
\hline \multirow{2}{*}{ 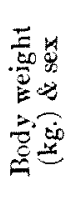 } & \multirow{2}{*}{ Time of observation } & \multirow{2}{*}{ 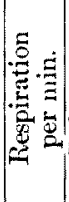 } & \multirow{2}{*}{ 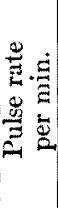 } & \multirow{2}{*}{ 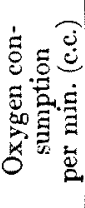 } & \multirow{2}{*}{ 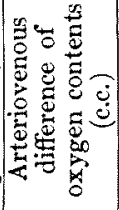 } & \multicolumn{2}{|c|}{$\begin{array}{l}\text { Minute } \\
\text { volume }\end{array}$} & \multicolumn{2}{|c|}{$\begin{array}{l}\text { Stroke } \\
\text { volume }\end{array}$} \\
\hline & & & & & & نُ & 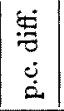 & نْ & 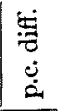 \\
\hline $\begin{array}{c}2.15 \\
?\end{array}$ & $\begin{array}{l}\text { Before compression } \\
1 \mathrm{hr} \text {. after 1st compression } \\
1 \mathrm{hr} \text {. after decompression } \\
2 \mathrm{hrs} \text {. after decompression } \\
1 \mathrm{hr} \text {. after } 2 \text { nd compression } \\
1 \mathrm{hr} \text {. after decompression }\end{array}$ & $\begin{array}{r}120 \\
62 \\
76 \\
74 \\
74 \\
100\end{array}$ & $\begin{array}{l}228 \\
216 \\
228 \\
228 \\
210 \\
222\end{array}$ & $\begin{array}{l}28.47 \\
21.25 \\
25.65 \\
21.71 \\
17.28 \\
16.01\end{array}$ & $\begin{array}{l}0.11629 \\
0.13569 \\
0.09468 \\
0.09550 \\
0.13829 \\
0.09640\end{array}$ & $\begin{array}{l}246 \\
157 \\
271 \\
227 \\
125 \\
165\end{array}$ & $\begin{array}{l}-36 \\
+10 \\
-8 \\
-49 \\
-33\end{array}$ & $\begin{array}{l}1.08 \\
0.73 \\
1.19 \\
1.00 \\
0.60 \\
0.73\end{array}$ & $\begin{array}{r}-32 \\
+10 \\
-7 \\
-44 \\
-32\end{array}$ \\
\hline
\end{tabular}


in Table II. In this second examination it was found that the decreases of the minute volume, the stroke volume and oxygen consumption as well as the increase of the oxygen utilisation have the same tendency as the results shown in Table I, but in adding the second compression in the respiration apparatus the grade of the variations was greater than that in the first observation.

\section{Discussion.}

The experiments indicate that in non-anaesthetised rabbits the minute volume is remarkably influenced by a respiration of compressed air up to $14 \mathrm{~cm}$. of water. That one hour after the exposure to compressed air the minute volume of the heart shows a considerable decrease may probably be based on the following fact:- - since the pressure of the compressed air acting on the inside surface of pulmonary alveoli has an effect upon the great endothoracic veins as well as on the weak parts of the heart muscles, the blood-flow can not easily stream into the endothoracic veins on account of the disturbed condition of the heart, and in turn stasis is aroused in the peripheric venous system, whereby the blood-flow returning to the right side of the heart is reduced. It is also probable that the high pressure in the pulmonary alveoli affects the pulmonary capillaries, and, accordingly, the passage of blood from the pulmonary arteries to the pulmonary veins is interfered with. Through these two factors the blood-flow to the left ventricle is necessarily decreased, and consequently the output from the ventricle to the aorta also. Two hours after exposure at excess pressure, the minute volume does not differ a great deal from that of the first hour after the inhalation of the compressed air, but on account of the continued forced respiration, the respiration and circulation become so fatigued that in some cases the minute volume shows a tendency to decrease sightly. After the cessation of the respiration of compressed air the general conditions returning to the former state, the causes of the circulatory disturbances are taken away, with the result that the minute volume gradually shows a tendency to recover, augmenting more or less one hour after the normal respiration, but since the respiratory and circulatory system have not yet sufficiently recovered from the fatigue, it has not yet reached the initial value. Two hours afterwards the minute volume increases further. Of course in these variations, anaemia due to the taking of blood several times, and an enfeeblement of the heart owing to the repeated cardiac punctures may fairly take part. The fact that the minute volume does not recover 
completely after the cause is removed is presumably related to these accessory changes. A conspicuous decrease in the minute volume in the second observation mentioned above may also oceur from the same process.

The variation of the stroke volume can also be explained as occurring for the same reason as that of the minute volume.

It is beyond discussion that a decrease in the minute volume during the respiration of compressed air has a great effect upon gaseous and general metabolisms of tissues. A decrease in the oxygen consumption during the respiration of compressed air may be partly due to the decreased bloodvolume passing through the lungs per minute, which leads to a diminished oxygen intake in the lungs. But with this explanation alone the decrease in the oxygen consumption cannot be completely illustrated. A considerable increase in the arteriovenous difference of oxygen contents per c.c., i.e. the oxygen utilisation, during the respiration of compressed air is based on the prolonging of the time in which the blood and tissues are in contact with each other through the apillaries because of the decrease of the minute volume, and on the fuct that the tissues take up as much oxygen as possible from the unit volume of the blood in order to fulfill the demands of the tissues. With such a mechanism the obstacle of the gaseous and general metabolisms seems to be mitigated. If the total blood volume increases during the respiration of compressed air, as Motek $\mathrm{i}^{\text {t) }}$ of our I Laboratory observed, this fact can also relieve more or less the hindrance of gaseous and general metabolisms, which is provoked by the decrease in the minute volume.

\section{Conchusions.}

1. In rabbits the minute volume and the stroke volume of the heart are considerably decreased during the respiration of excessively compresed air up to $14 \mathrm{~cm}$. of water.

2. These alterations bring about a decrease in the oxygen consumption per minute and an increase in the arteriovenous difference of oxygen contents per c.c. i. e. the oxygen utilisation.

3. These alterations cease more or less, after the cessation of the respiration of the compressed air, and the former condition is recovered. 